\title{
Nontraumatic spontaneous splenic rupture in the third trimester of pregnancy: a case report
}

\section{Gebeliğin üçüncü üç aylık döneminde kendiliğinde gelişen dalak rüptürü: vaka sunumu}

\author{
Hasan Ali iNAL' ${ }^{1 a}$, Zeynep ÖZTÜRK INAL' \\ ${ }^{1}$ Department of Gynaecology and Obstetrics, Konya Research and Training Hospital, Konya, Meram, TURKEY
}

\begin{abstract}
Spontaneous splenic rupture in pregnancy is a rare but life-threatening complication requiring urgent surgical intervention. If it remains unrecognized, it can be fatal for both mother and baby. Herein, we present a case of spontaneous rupture of a normal spleen at 28.4 weeks gestation. Early diagnosis and aggressive surgical intervention can provide maternal and fetal survival. In case of a suspected splenic rupture, urgent exploratory laparotomy via a midline vertical incision to allow visualization of and access to bleeding location should be performed to save mother's and baby's lives.
\end{abstract}

Key words: Pregnancy, rupture spontaneous, spleen

Öz

Kendiliğinden dalak rüptürü gebelikte nadir gözlenir fakat acil cerrahi müdahale gerektiren yaşamı tehdit eden bir komplikasyondur. Bu makalede 28,4 haftalık gebede kendiliğinden gelişen dalak rüptürü vakası sunulmuştur. Erken tanı ve hızlı cerrahi müdahale anne ve bebeğin hayatını kurtarılabilir. Dalak rüptüründe şüphelenildiği zaman, bebek ve anne hayatı için acil eksploratif laparatomi - kanama yerini görebilmek ve ulaşmak için karın orta hat kesi ile yapılan - yapılması gerekir.

Anahtar kelimeler: Gebelik, kendiliğinden rüptür, dalak

\section{Introduction}

Spontaneous splenic rupture in pregnancy rarely occurs and results from a trauma or a pre-existing pathology of the spleen such as infectious mononucleosis, leukemia, sarcoidosis, amyloidosis, and malaria [1]. Saxtorph [2] was the first to define splenic rupture in pregnancy. Orloff and Peskin [3] established the following four diagnostic criteria for spontaneous splenic rupture and put these criteria into practice; first no history of trauma, second no history of systemic diseases, third no evidence of perisplenic adhesions suggesting previous trauma, and last both macroscopically and histologically intact splenic parenchyma, vascularity and capsule.
The clinical picture mimics a ruptured ectopic pregnancy, placental abruption, uterine rupture and rupture of uterine vessels or other intra-abdominal vessels such as aneurysms [4]. Splenic rupture during delivery or early postpartum generally occurs due to traumatic incidents, and maternal and fetal mortality are high [5].

The treatment of spontaneous splenic rupture in pregnancy requires splenectomy and blood replacement. However, preoperative diagnosis is rather difficult, and most cases may remain misdiagnosed which leads to a delay in surgical intervention [1].

Herein, we present a case of spontaneous rupture of a normal spleen at 28.4 weeks gestation. 


\section{Case Report}

A 28 year-old woman (gravida II, parity I) who had a history of collapse in the ambulance on her way to the hospital was admitted to the delivery room. After the collapse, she was disoriented, cold, pale, and had a blood pressure of 80/50 $\mathrm{mmHg}$. She did not have any antepartum examinations during the course of her pregnancy. In the delivery room, her blood pressure decreased to $60 / 40 \mathrm{mmHg}$ with a pulse rate of $120 / \mathrm{min}$. On her physical examination, diffuse abdominal tenderness with rebound and guarding was observed. She had no visible signs of trauma. Intravenous access was established. The patient was immediately given plasma expanders and oxygen. She had no contractions, and the cervical opening was $2 \mathrm{~cm}$. On fetal monitoring, a prolonged fetal heart rate deceleration to 80 beats/min was noted, and no uterine contractions were observed.

Laboratory results revealed increased leukocytes (19.7 x109/L), and reduced erythrocytes (3.37 x109/L) and hemoglobin (7.5 $\mathrm{g} / \mathrm{dl}$ ) levels. Coagulation tests, platelets and liver enzymes were within normal range.

The patient's condition worsened, and pregnancy was terminated with emergency caesarean section due to the occurrence of clinical signs of hemorrhagic shock soon after. On entry into the abdominal cavity, approximately $3.5 \mathrm{~L}$ blood and coagulum were observed and aspirated. A low transverse hysterotomy was carried out, a clear amniotic fluid was observed, and a viable male infant was delivered. The birth weight, birth length and Apgar scores of the newborn were $1150 \mathrm{~g}, 39 \mathrm{~cm}$, and 1/3/6, respectively. The umbilical cord blood $\mathrm{pH}$ was 6.91. The gestational age was estimated to be 28.4 weeks. The decision-to-delivery time was $10 \mathrm{~min}$. The adnexa appeared normal bilaterally. The abdominal incision was vertically extended, and an active bleeding was noted at the splenic hilum. This finding was consistent with splenic rupture (Fig. 1), and the patient underwent a splenectomy performed by a general surgeon, the rest of the surgery was uneventful.

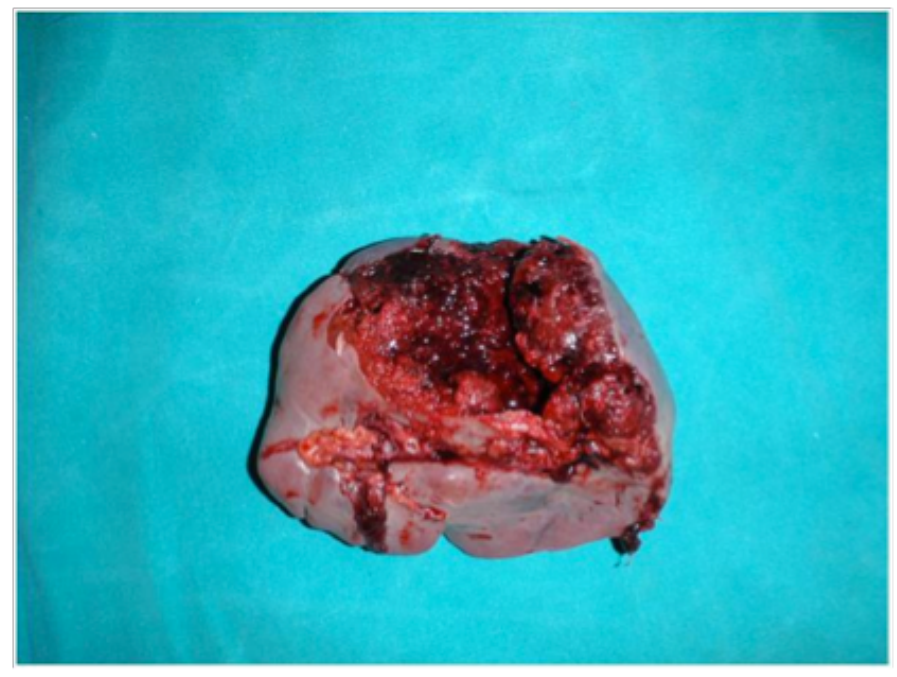

Fig 1. Macroscopic appearance of the splen.
The total measured blood loss of the patient was $3900 \mathrm{~mL}$. Totally, 12 units of packed red blood cells and 4 units of frozen plasma were administered. The postoperative course was unremarkable, and the patient was discharged on the postoperative day 10 . The newborn was hospitalized in the neonatal intensive care unit for 35 days and discharged without complications.

\section{Discussion}

We report a case of spontaneous idiopathic rupture of a normal spleen at 28 weeks gestation leading to hemorrhagic shock and acute uteroplacental hypoperfusion. The present case was initially diagnosed with placental abruption; however, due to the occurrence of marked clinical signs of hemorrhagic shock, the patient was immediately operated. Owing to rapid surgical intervention, the mother and the baby both survived.

Splenic rupture in pregnancy commonly occurs with a history of trauma at the third trimester of multiple pregnancies in older women. The factors increasing the intra-abdominal pressure such as coughing and vomiting may be responsible for the etiology of splenic rupture in pregnancy. In addition, the hemodynamic changes like increased circulating blood volume and increased circulating hormones such as estrogen and progesterone may cause structural changes to the spleen and may increase the risk of splenic rupture during pregnancy [6]. The major problem associated with splenic rupture in pregnancy is late or misdiagnosis. Splenic rupture in pregnancy is generally mistaken for placental abruption, uterine rupture or ectopic pregnancy [7].

The most frequent clinical symptom is abdominal pain that radiates to the left shoulder. If rupture is not identified or suspected, the patient's condition rapidly worsens and hemorrhagic shock may occur [8]. If the patient is hemodynamically stable, pelvic/abdominal ultrasound and computed tomography are useful diagnostic tools to be used [9]. However, rupture is noticed during surgical exploration in a great majority of the cases. If emergent surgical intervention is not carried out, maternal and fetal deaths are inevitable due to hemorrhagic shock and disseminated intravascular coagulation $[10,11]$.

In conclusion, spontaneous or traumatic splenic rupture in pregnancy is a life-threatening condition. If a pregnant woman with hypotension, tachycardia, collapse or generalized abdominal pain applies to emergency ward or delivery room, the possibility of splenic rupture should be considered in addition to placental abruption, uterine rupture or ectopic pregnancy.

\section{Declaration of conflicting interests}

The authors declared no conflicts of interest with respect to the authorship and/or publication of this article.

\section{Funding}

The authors received no financial support for the research and/or authorship of this article. 


\section{References}

1. Hoffman RL. Rupture of the spleen. A review and report of a case following abdominal hysterectomy. Am J Obstet Gynecol 1972; 113: 524-30.

2. Saxtorph M. Cited by Schwing C. Ruptur der Milz waehrend der Schwaenger schaft Ruptur. Zbl Gynaekol 1980; 4: 291.

3. Orloff MJ, Peskin GW. Spontaneous rupture of the normal spleen; a surgical enigma. Int Abstr Surg 1958; 106: 1-11.

4. Furler IK, Robertson DNS. Spontaneous rupture of the splenic artery in pregnancy. Lancet 1962; 2: 588-90.

5. Epstein M, King R, Kenney D. Splenic rupture at term. Case report. Missouri Med 1983; 80:83-4.

6. Di Vella G, Arpaio A, Marzullo A, Colonna M. Rupture of the spleen or splenic vessels (splenic emergency syndrome) in late pregnancy: a report of two autopsy cases. Forensic Sci Int 2008; 176: $1-5$
7. Bljajic D, Ivanisevic M, Djelmis J, Majerovic M, Starcevic V. Splenic rupture in pregnancy - traumatic or spontaneos event? Eur J Obstet Gynecol Reprod Biol 2004; 115: 113-4.

8. Sakhel K, Aswad N, Usta I, Nassar A. Postpartum splenic rupture. Obstet Gynecol 2003; 102: 1207-10.

9. Lubner M, Menias C, Rucker C, et al. Blood in the belly: CT findings of hemoperitoneum. Radiographics 2007; 27:109-25.

10. Wang C, Tu X, Li S, Luo G, Norwitz ER. Spontaneous rupture of the spleen: a rare but serious case of acute abdominal pain in pregnancy. J Emerg Med 2011; 41: 503-6.

11. de Graaff J, Pijpers PM. Spontaneous rupture of the spleen in third trimester of pregnancy. Report of a case and review of the literature. Eur J Obstet Gynecol Reprod Biol 1987; 25: 243-7. 